\title{
Diseño y construcción de las bóvedas por cruceros en España durante el siglo XVI
}

\author{
Design and construction of grid crossing vaults in Spain \\ during the 16th century
}

L. C. Palacios ${ }^{(*)}$, S. C. Bravo ${ }^{(*)}$

\section{RESUMEN}

El objetivo de este texto es dar a conocer las pautas históricas, de diseño y construcción de las bóvedas por cruceros erigidas en España durante el siglo XVI, como muestra de cómo la tradición gótica de construir bóvedas con nervaduras pudo adaptarse a los principios estéticos clásicos.

En la Andalucía del siglo XVI, una arquitectura clásica renacentista y otra gótica extraordinariamente evolucionada alcanzaron, al mismo tiempo, su pleno desarrollo; entre ambas se produjeron interesantes transferencias de conocimiento, estilísticas y técnicas. En este sentido, las bóvedas por cruceros constituyen un notable ejemplo de autonomía formal de la nervadura gótica que, sin perder sus principios constructivos medievales, es capaz de adaptarse a modelos renacentistas. Veremos como en las bóvedas por cruceros, las crucerías góticas se adaptan a la forma de una trama reticular clásica, dibujando sobre la superficie de la bóveda un diseño de casetones conforme al canon romano más estricto.

970-8

Palabras clave: Bóveda; bóveda baída; bóveda por cruceros; renacimiento; gótico; estereotomía.

\section{SUMMARY}

The aim of this text is to present the historical guidelines, design and construction of the grid crossing vaults built in Spain during the 16th century to show how the Gothic tradition of building ribbed vaults could be adapted to classical aesthetic principles.

In the Andalusia of the 16th century, both a Renaissance classical architecture and another extraordinarily evolved Gothic one reached, at the same time, their full development, taking place between them interesting knowledge, stylistic and technical transfers. In this respect, the grid crossing vaults are a remarkable example of the formal autonomy of Gothic ribs which, without losing their medieval construction principles, are capable of adapting themselves to Renaissance models. We will see how in the grid crossing vaults, the Gothic crossings adapted themselves to the shape of a classical grid structure, drawing on the surface of the vault a design of caissons according to the stricter Roman Canon.

Keywords: Vault; Pendentive vault; Grid crossing vault; Renaissance; Gothic; stereotomy. 


\section{MARCO HISTÓRICO}

Tras el descubrimiento de América en 1492, Sevilla se convirtió en el centro económico del Imperio español. Los Reyes Católicos fundaron la Casa de Contratación, desde donde se dirigían y contrataban los viajes, controlaban las riquezas que entraban de América y regulaban las relaciones con el Nuevo Mundo. Durante el siglo XVI la ciudad experimentó un gran desarrollo y transformación; se construyeron algunos de los edificios más importantes de la época. Es en este contexto en el que tuvieron su origen las bóvedas por cruceros en Andalucía, específicamente en Sevilla y sus alrededores.

Los autores. Los maestros mayores del siglo XVI que diseñaron y construyeron la mayoría de las bóvedas por cruceros en España son Diego de Riaño y Martín de Gainza. Nacieron en el norte peninsular a finales del siglo XV, lo que los sitúa en los talleres de cantería gótica durante su periodo de aprendizaje. Diego de Riaño es el autor del diseño y construcción de la primera bóveda por cruceros. Ésta se encuentra en la iglesia de San Miguel en Morón de la Frontera, Sevilla, cubriendo el primer tramo de la nave central (Figura 1). A esta primera bóveda la podemos datar cerca del año 1523 (1).

Diego de Riaño es llamado, en 1526, por la corte del rey Carlos I de España para diseñar las casas consistoriales sevillanas. Diseña las dependencias del costado sur del ayuntamiento, entre las cuales se encuentra la espléndida bóveda por cruceros de la sala capitular, la bóveda de la Sala de Fieles Ejecutores y el arquillo exterior. A la muerte de Riaño acaecida en 1534, Martín de Gainza, quien trabajaba como aparejador principal, se convierte en maestro mayor de esta obra y lleva a buen término la construcción de las bóvedas (2). Como aparejador, Martín de Gainza se convirtió, a la muerte de Riaño, en el maestro mayor de la mayoría de las obras que dirigía éste.

En 1526, el cabildo de la catedral sevillana nombra como maestro de obras de las nuevas dependencias del costado sur de la catedral a Diego de Riaño, cargo que se le atribuye por ser el maestro mayor real de las casas consistoriales de la misma ciudad. Riaño diseña, entre otras estancias, la sacristía mayor y la casa de cuentas cubriéndolas con bóvedas por cruceros (3).

Otras obras que dirigen Riaño y Gainza de 1528 hasta 1546, fecha de la muerte de Gainza, se encuentran en pueblos cercanos a Sevilla, en Andalucía occidental. Todas estas obras se cubren en su totalidad

\section{HISTORICAL FRAMFWORK}

After the discovery of America in 1492, Seville became the economic centre of the Spanish Empire. The Catholic Monarchs founded the Casa de Contratación (Indian Trading Company), from where they contracted and directed the voyages, controlled the wealth that came from America and regulated the relations with the New World. During the 16th century, this city experienced a great development and transformation; some of the most important buildings of the time were built then. It is in this context where the grid crossing vaults had their origin in Andalusia, specifically in Seville and its surroundings.

The authors. The great masters of the 16th century who designed and built most of the grid crossing vaults in Spain are Diego de Riaño and Martín de Gainza. They were born in the North of Spain at the end of the 15th century, which places them in the Gothic stone masonry workshops during their period of learning. Diego de Riaño is the author of the design and construction of the first grid crossing vault. It is located in the Church of San Miguel in Morón de la Frontera, Seville, covering the first section of the central nave (Figure 1). This first vault probably dates back to around 1523 (1).

In 1526, Diego de Riaño is called to the Court of King Carlos I of Spain to design the Seville Town Hall. He designs the southern end of the building, including the splendid grid crossing vault of the chapterhouse, the vault of the room known as Sala de los Fieles Ejecutores, and the small outside arch. After the death of Riaño in 1534, Martín de Gainza, who was then working as a main quantity surveyor, becomes the Master builder of this work and completes the construction of the vaults (2). As a quantity surveyor, Martín de Gainza became, after the death of Riaño, the Master builder of most of his works.

In 1526, the Chapter of Seville cathedral appoints Diego de Riaño work master of the new premises of the southern end of the cathedral, a position conferred to him for being the royal master builder of the town hall of that city. Riaño designs, among other rooms, the Sacristía Mayor (main sacristy) and the Casa de Cuentas (account house), covering them with grid crossing vaults. (3)

Other works which Riaño and Gainza direct from 1528 to 1546, the date of Gainza's death, are located in villages near Seville, in Western Andalusia. All these works are totally or partially covered with grid crossing vaults. Among these buildings, it 
o en parte con bóvedas por cruceros. Entre estas edificaciones cabe resaltar, por orden cronológico, la iglesia de la Asunción en Aracena, Huelva; la iglesia del Rosario en Zafra, Badajoz, antiguamente Andalucía; el monasterio de San Jerónimo de Buenavista en los límites de la ciudad de Sevilla; la iglesia de la Asunción en Carmona, Sevilla; y la iglesia de la Consolación en Cazalla de la Sierra, Sevilla (Figura 2). Así pues, podemos afirmar que Diego de Riaño y Martín de Gainza, son los principales exponentes de este tipo de bóvedas en España; ellos lograron fundir sus conocimientos de la nervadura gótica con los diseños renacentistas de la primera mitad del siglo XVI.

Durante la segunda mitad del siglo, se construyeron algunas otras bóvedas por cruceros en el norte de la península lbérica. De estas bóvedas las que merecen una particular atención por sus dimensiones son las que cubren la totalidad de la iglesia de San Sebastián Soreasu, Azpeitia, en Guipúzcoa, diseñadas y construidas por los hermanos Armendia; y las que cubren la iglesia de San Nicolás de Bari en Orio, también en Guipúzcoa, cuyo autor es Juan de Landarraín; ambos templos se levantaron entre las décadas de 1560 y 1570, según recuerda una inscripción tallada en piedra en ambos casos.

Por tanto, la mayoría de las bóvedas por cruceros en España se construyeron en la primera mitad del siglo XVI, terminando con los últimos ejemplos en el norte de la península. is worth noting, in chronological order, the Church of the Asunción in Aracena, Huelva; the Church of the Rosario in Zafra, Badajoz, a former Andalusian region, the monastery of San Jerónimo de Buenavista in the boundaries of the city of Seville; the Church of the Asunción in Carmona, Seville; and the Church of the Consolación in Cazalla de la Sierra, Seville (Figure 2). Thus, we can say that Diego de Riaño and Martín de Gainza, are the greatest exponents of this type of vaults in Spain; they succeeded in merging their knowledge of Gothic ribs into the Renaissance designs of the first half of the 16th century.

During the second half of that century, some other grid crossing vaults were built, in the North of the Iberian Peninsula. Among them, the vaults that deserve a particular attention due to its size are those which cover the whole Church of San Sebastian Soreasu, Azpeitia, in Guipuzcoa, designed and built by the Armendia brothers; and those which cover the Church of San Nicolás de Bari, in Orio, also in Guipuzcoa, whose author is Juan de Landarrain; both temples were built between 1560 and 1570, as recalled by the inscription carved in stone in both places.

Therefore, most of the grid crossing vaults in Spain were built in the first half of the 16th century and the last examples built can be found in the North of Spain.
1. Bóveda que cubre el primer tramo de la iglesia de San Migue en Morón de la Frontera, Sevilla. Autor: Diego de Riaño.

1. Vault covering the first part of the Church of San Miguel in Morón de la Frontera, Seville. Author: Diego de Riaño.

2. Bóvedas por cruceros con trama diagonal y perpendicular. Iglesia de Nuestra Señora de la Consolación. Cazalla de la Sierra, Sevilla.

2. Grid crossing vaults with perpendicular and diagonal grid. Church of Nuestra Señora de Consolación. Cazalla de la Sierra, Seville.
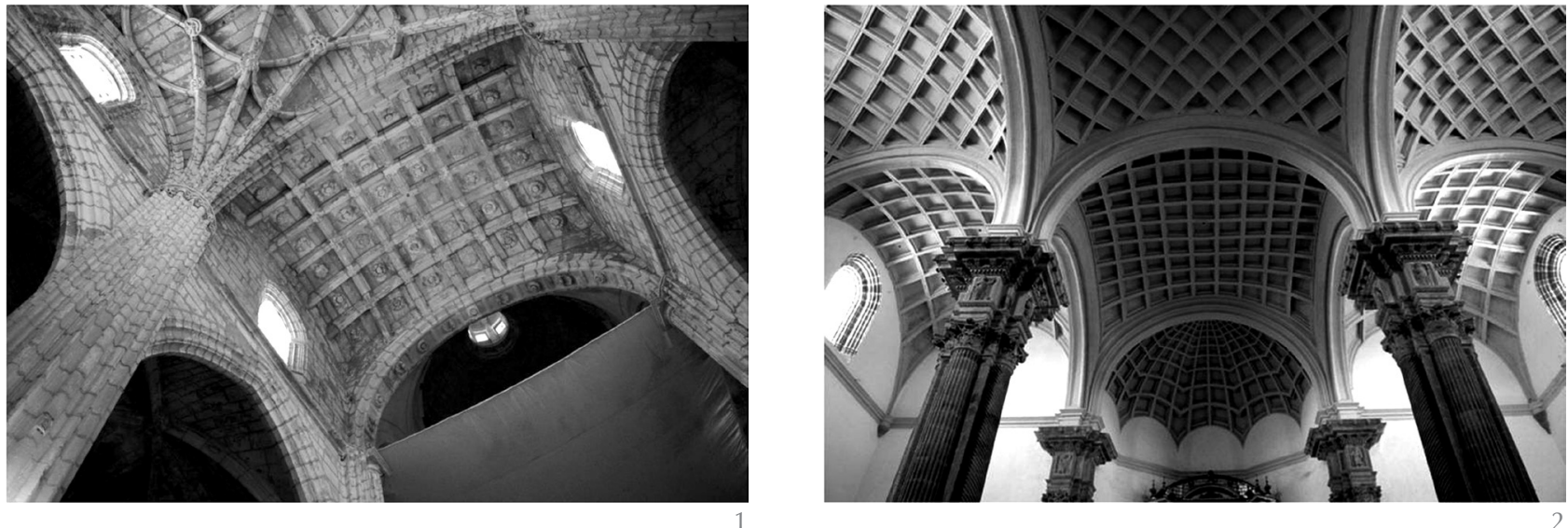

\section{LAS BÓVEDAS POR CRUCEROS EN EL TRATADO DE ALONSO DE VANDELVIRA}

Las bóvedas por cruceros merecieron un profundo estudio en el tratado de Alonso de Vandelvira, publicado en España en 1591. En este tratado aparecen cinco modelos diferentes de bóvedas por cruceros, los dos primeros muestran bóvedas con los cruce-

\section{THE GRID CROSSING VAULTS IN THE TREATISE OF ALONSO DE VANDELVIRA}

The grid crossing vaults deserved an indepth study in the treatise of Alonso de Vandelvira, published in Spain in 1591. There are five different models of grid crossing vaults in this treatise; the first two show vaults with the crossings forming an 
ros dispuestos formando una trama ortogonal paralela a los arcos del perímetro, la primera es de planta cuadrada (Figura 3), y la segunda de planta rectangular. Las tres restantes, son bóvedas en las que la trama se dispone paralela a las diagonales; en el tratado, estas bóvedas reciben el nombre de capillas enrejadas (4).

La característica primordial de las bóvedas por cruceros que desarrolla Vandelvira es que todas ellas son bóvedas baídas, es decir esféricas. Esta circunstancia permite a Vandelvira proponer, para la talla de sus cruceros, una traza geométrica basada en la estereotomía de las cúpulas esféricas, es decir, mediante la plantilla de la cara de intradós. La obtención de la cara de intradós de cualquiera de las dovelas que componen una cúpula es una de las habilidades geométricas más extraordinarias de la estereotomía del Renacimiento. Desconocemos donde tiene su punto de partida pero, probablemente, tiene mucho que ver con la estereotomía de las trompas (5) ya que el método parte de contemplar una cúpula como una sucesión de conos coaxiales. Así pues, las plantillas de las caras de intradós de cada lecho se obtienen a través del desarrollo de superficies cónicas. En las bóvedas por cruceros de Vandelvira, al ser esféricas, cada uno de los cruceros puede inscribirse en una plantilla cuya forma se puede calcular geométricamente mediante el método anteriormente reseñado. Esta plantilla permitiría tallar una dovela trapezoidal que sería el sólido contenedor de cada crucero.

Si las bóvedas por cruceros fueran esféricas como Vandelvira propone, todos los arcos que forman la parrilla de nervios tendrían curvaturas diferentes, lo cual significa que, cada arco, requiere su colección de dovelas talladas con la curvatura precisa. Pocas de las bóvedas por cruceros existentes en España son superficies esféricas; con frecuencia, son superficies de traslación en las que un solo arco se mueve en las dos direcciones ortogonales. La bóveda obtenida puede parecer esférica pero es incomparablemente más fácil de ejecutar ya que todos sus arcos son iguales.

\section{DESARROLLO DE LA GEOMETRÍA DE LAS BÓVEDAS POR CRUCEROS}

Como anteriormente mencionamos, las bóvedas por cruceros son bóvedas formadas por una parrilla de nervaduras ortogonales compuesta por una serie de dovelas en forma de cruz que se van ensamblando, unas con otras, hasta formar una red espacial ortogonal (Figura 4). Por tanto, la diferencia con las bóvedas góticas consiste en que la nervadura, en lugar de partir de las cuatro orthogonal grid parallel to the arches of the perimeter, the first one has a square ground plan (Figure 3), and the second one has a rectangular ground plan. The remaining three are vaults in which the grid is parallel to the diagonal lines; in the treaty, these vaults are called grilled chapels (capillas enrejadas)(4).

The main feature of the grid crossing vaults developed by Vandelvira is that they are all pendentive vaults, that is, spherical vaults. This fact enables Vandelvira to propose, for the carving of its crossings, a geometric trace based on the stereotomy of spherical domes, that is, with the template of the face of intrados. Obtaining the face of intrados of any of the voussoirs which make up a dome is one of the most extraordinary geometric skills of the Renaissance stereotomy. We do not know where it has its starting point but, it probably has much to do with the stereotomy of pendentive vaults (5), since the method starts by considering a vault as a succession of coaxial cones. So, the template of the faces of intrados of each bed is obtained through the development of conical surfaces. As Valdevira's grid crossing vaults are spherical, each of the crossings can be inscribed on a template whose shape can be calculated geometrically using the method previously described. This template would enable him to carve a trapezoidal voussoir that would be the solid receptacles of each crossing.

If the grid crossing vaults were spherical as proposed by Vandelvira, all the arches which form the rib grid would have different curvature, this means that each arc requires its set of voussoirs carved with the precise curvature. Few of the grids crossing vaults which exist in Spain are spherical surfaces; they are often translation surfaces in which a single arc moves towards both orthogonal directions. The vault obtained may seem spherical, but it is incomparably easier to build since all its arches are equal.

\section{GEOMETRY DEVELOPMENT OF THE GRID CROSSING VAULTS}

As previously mentioned, the grid crossing vaults are vaults formed by an orthogonal rib grid consisting of a series of crossshaped voussoirs which are assembled to each other into an orthogonal spatial net (Figure 4). Therefore, the difference with Gothic vaults is that the ribs, instead of springing from the four corners towards the central keystone, form a grid which, like a net, covers all the surface of the vault. Their formal appearance is clearly Renaissance; however, the construction technique of these vaults is based on Gothic principles. 
esquinas hacia la clave central, forma una cuadrícula que, como una red, cubre la totalidad de la superficie de la bóveda. Su aspecto formal es claramente renacentista; sin embargo, la técnica de construcción de estas bóvedas se basa en principios góticos.

Como hemos dicho, Vandelvira afirma que son bóvedas esféricas. Sin embrago advertimos la extrema dificultad que se deriva de una bóveda baída: cada crucero (intersección de nervios) que se genera se produce por la intersección de dos circunferencias de distinto radio. Frente a este inconveniente los maestros góticos adaptaron el principio de estandarización de los arcos en las bóvedas medievales. Así pues, esta dificultad fue soslayada utilizando un solo arco, es decir, que el arco fajón, o arco perimetral, se desplaza en ambas direcciones, generando una superficie de traslación (6).

En una hipotética bóveda de traslación donde el arco formero de medio punto se repitiese por toda la superficie abovedada, resultaría una carcasa bastante apepinada Para contrarrestar el exceso de peralte se diseñaron bóvedas por cruceros rebajadas, definiendo arcos escarzanos sobre los arcos formeros de medio punto. Este es el caso de la bóveda que se encuentra sobre el primer tramo de la nave central de la iglesia de San Miguel en Morón de la Frontera, Sevilla (Figura 1). En la bóveda central de la iglesia de Cazalla de la Sierra se resuelve la unión entre la carcasa y los arcos formeros de medio punto mediante un conjunto de molduras clásicas que adaptan su grosor a la diferencia de altura por cubrir. En las capillas donde la bóveda está contenida en un espacio cerrado, los muros absorben el arco escarzano que define el perímetro de la superficie abovedada.

El grado de estandarización máximo alcanzado en este tipo de bóvedas se concreta logrando que los arcos fajones y la totalidad de los nervios compartan la misma curvatura; con lo que con un solo radio de curvatura se tallan todas las dovelas de la

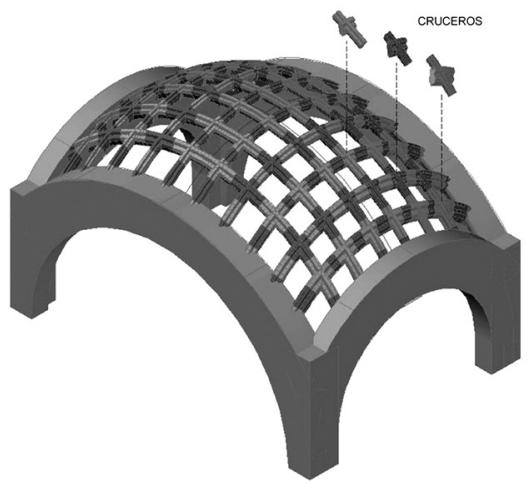

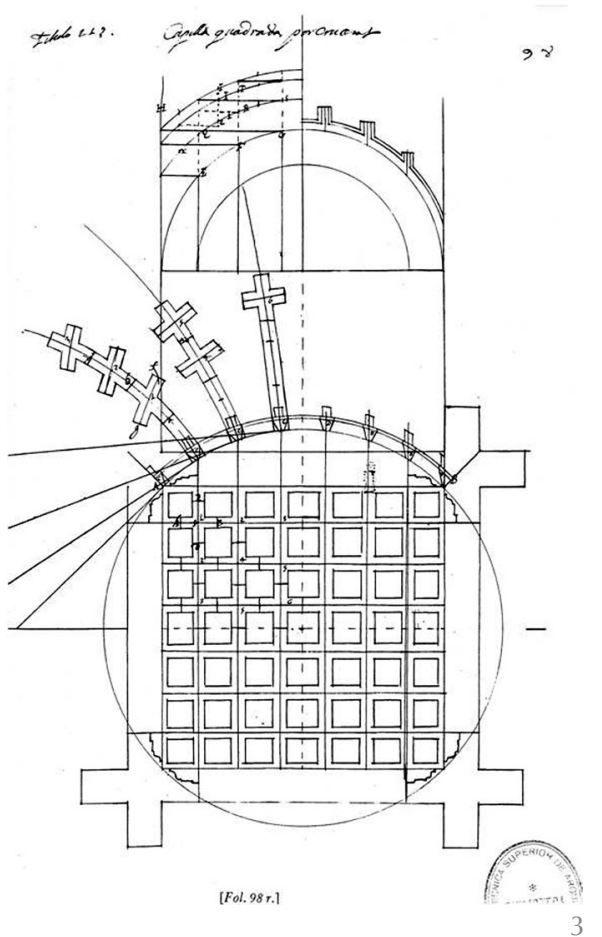

As we said before, Vandelvira affirms that they are spherical vaults. However, we are aware of the extreme difficulty that a pendentive vault involves: each crossing (intersection of ribs) generated is produced due to the intersection of two circumferences of different radius. Facing this problem, the Gothic masters adapted the principle of the standardization of arches in medieval vaults. So, this difficulty was avoided by using a single arc; that is, the wall-rib moves in both directions and generates a translation surface (6).

In a hypothetical translation vault where the semi-circular edge arch (wall-arch) was repeated all along the vaulted surface, a rather cucumber-shaped shell would eventually be formed. In order to counteract the excess of volume that would result in a vault built under these principles, segmental grid crossing vaults were designed, forming segmental arches over the semi-circular transversal arches. An example of this is the vault which covers the first part of the central nave in the church of San Miguel in Morón de la Frontera, Seville (Figure 1). In the central vault of the church of Cazalla de la Sierra, the shell and the semi-circular transversal arches are joined together by a group of classic moldings which adapt their thickness to the difference of height to be covered. In the chapels where the vault is contained in an enclosed space, the walls soften the segmental arches that define the perimeter of the vaulted surface.

The maximum standardization degree obtained in this type of vaults is materialized when the transverse arches and all the ribs
3. Bóveda por cruceros de planta cuadrada y trama ortogona paralela a los arcos perimetrales. Folio 98 del tratado de Vandelvira (1591).

3. Grid crossing vault of square ground plan and orthogonal grid parallel to the wall-arches. Sheet 98 of Vandelvira's Treatise.

4. Modelo virtual 3D de una bóveda por cruceros.

4. $3 D$ virtual model of a grid crossing vault. 
bóveda (arcos fajones y nervios). En este tipo de bóvedas por cruceros, los arcos formeros son de tipo carpanel u oval, donde la circunferencia central que forma el óvalo define la curvatura en todas las nervaduras. Este es un recurso claramente eficaz ya que facilita sobremanera la talla de toda la bóveda al tener un radio de circunferencia para todas las dovelas.

\section{CONSTRUCCIÓN}

Una vez que el maestro cantero definía la geometría de la bóveda, se daba paso al dibujo de sus monteas. Este término, muy utilizado en el siglo XVI, hace referencia a los dibujos realizados a tamaño natural del conjunto o de parte de la obra, en este caso de las bóvedas. De estos dibujos se extraían datos imprescindibles para su construcción. Las herramientas indispensables para transportar los datos de estos dibujos a la piedra eran las plantillas de las caras de las dovelas, los baibeles, instrumento de origen medieval fundamental en cantería que permitía tallar con la curvatura precisa las caras de intradós de las dovelas, y las saltarreglas para transportar los ángulos que forman las diversas caras de una dovela entre sí.

La traza de las plantillas se obtenía de las monteas realizadas a tamaño natural lo que, a pesar de su incomodidad, tiene la indudable ventaja de la exactitud ya que, en el siglo XVI, un cambio de escala era una operación arriesgada que podía conllevar fatales errores. La traza de estos patrones a tamaño natural se hacía sobre el propio pavimento del edificio a construir, o sobre una superficie plana dispuesta a tal fin en las "salas de trazas", estancias dedicadas a tal fin desde la Edad Media. Gigantescas construcciones geométricas sobre el suelo o las paredes irían acompañando la construcción de las diversas estancias del edificio renacentista (Figura 5).

Siguiendo los criterios anteriormente expuestos, se trazaban las curvaturas de los arcos utilizando para todos ellos el mismo radio de circunferencia. Posteriormente, se dibujaban con detalle los despieces con los que construir las otras partes de la bóveda: cruceros, dovelas y jarjas.

Alonso de Vandelvira advierte en su tratado que este tipo de bóvedas pueden construirse con arcos de molde cuadrado o de molde revirado. Es este un aspecto fundamental en la construcción de una bóveda de este tipo, ya que los cruceros (las piezas más complejas e importantes) dependen have the same curvature; so all the voussoirs of the vault (transverse arches and ribs) are built with a single radius of curvature. In this type of grid crossing vaults, the transverse arches are basket or oval, where the central circumference which forms the oval defines the curvature in all the ribs. This is a clearly effective resource since it makes the carving of the whole vault a much easier job as we have a radius of circumference for all the voussoirs.

\section{CONSTRUCTION}

Once the Master masons defined the geometry of the vault, the next step was drawing its monteas. This term, widely used in the 16th century, refers to the life-size drawings made of all or part of the work, in this case of the vaults. Essential information for their construction was extracted from these drawings. The indispensable tools to take the information from these drawings to the stone were the templates of the faces of the voussoirs, the bebels, an instrument of medieval origin and essential in masonry that enabled to carve the faces of intrados of the voussoirs with the precise curvature, and the saltarreglas for transporting the angles that the different faces of a voussoir form between them.

The tracing of patterns was obtained from the monteas or full-size plans which, despite being uncomfortable, have the unquestionable advantage of their accuracy, since in the 16th century a change of scale was a risky operation that could lead to fatal errors. The tracing of these life-size patterns was made on the pavement of the building or on a flat surface prepared for this purpose in "tracing rooms", large rooms used for this purpose since the middle ages. Gigantic geometric constructions on the floor or the walls would accompany the construction of the various rooms of the Renaissance building (Figure 5).

Following the previously mentioned criteria, the curvatures of the arches were traced using the same radius of circumference for all of them. Subsequently, the plans with which to build the remaining parts of the vault were drawn in detail: crossings, voussoirs and tas-de-charge.

Alonso de Vandelvira explains in his treaty that this type of vaults can be built with square arches or distorted arches. This is an essential aspect in the construction of a vault of this type, since the crossings (the most complex and important parts) depend on the combination and position of these distorted arches within the volume of the vault. According to the Gothic tradition, the 
de la combinación y posición de estos revirados dentro de la volumetría de la bóveda. Acorde con la tradición gótica, los nervios de molde revirado mantienen vertical el eje de su sección, cualquiera que sea la posición que este arco ocupe en la bóveda. Esta circunstancia hace que las secciones de todos los arcos varíen, desde la cúspide de la bóveda hasta su perímetro, donde los reviros, es decir las deformaciones, son máximas. Por el contrario, en los arcos de molde cuadrado la sección permanece inalterada ya que su eje de simetría es radial, es decir que se orienta siempre hacia el centro de la bóveda (Figura 6).

La justificación que explica la existencia de las secciones reviradas frente a los nervios cuadrados, comunes en el Renacimiento, hay que buscarlos sin duda en la tradición medieval. Recordemos que las nervaduras góticas son siempre verticales, es decir, que orientan todos sus ejes según la vertical de la bóveda.

La construcción formal de las bóvedas por cruceros en el siglo XVI se comenzaba con la labra de dovelas, las piezas que unen a los cruceros entre sí. Para realizar esta operación de talla, la herramienta fundamental era el baibel. El proceso por tanto es el siguiente: primeramente, a partir de las monteas, se confeccionan los baibeles con la curvatura de intradós de los nervios, posteriormente se hacen las plantillas de las secciones que para los nervios es revirada en la mayor parte de los casos. A continuación, con la ayuda del baibel se corta un bloque de piedra logrando exactamente la curvatura de intradós; posteriormente, en los extremos de la pieza, se traza la plantilla de testa con el revirado adecuado. Por último se da la forma a cada dovela quitando el material distorted ribs keep the axis of their section upright whatever the position of this arc in the vault is. This factor makes the sections of all the arches vary, from the top of the vault to its perimeter, where the reviros, that is, the distortions, are maximal. On the contrary, in the square arches, the section remains unchanged, since their symmetry axis is radial, that is, it is always oriented towards the center of the vault (Figure 6).

The reason which explains the existence of distorted sections as opposed to square ribs, common in the Renaissance, can be undoubtedly found in the medieval tradition. Let us remember that Gothic ribs are always vertical, that is, they orientate all their axis according to the vertical line of the vault.

The formal construction of the grid crossing vaults in the 16th century began with the stone-cutting of the voussoirs, the pieces which join the crossings to each other. To perform this stone-cutting operation, the essential tool was the bebel. The process is therefore as follows: first of all, we make the bebels from the monteas, with the intrados curvature of the ribs, then we make the patterns of the sections which in most cases is distorted for the ribs. Then, with the help of the bebel we cut a block of stone in order to get exactly the curvature of intrados. Subsequently, at the ends of the piece, we trace the testa pattern with the right distortion. Finally, we give shape to each voussoir by removing the excess material. It should be noted that in the Gothic building workshop of the Construction Department of the Superior Technical School of Architecture of Madrid (ETSAM), we have built a real grid crossing vault following the traditional construction process used in the
5. Montea en alzado necesaria para la construcción de una bóveda por cruceros.

5. Montea in elevation neces sary for the construction of a grid crossing vault.

6. Nervios de sección cuadrada con ejes orientados hacia el centro. Nervios de sección revirada con ejes verticales.

6. In the right section of the drawing can see the distorted ribs which, according to the Gothic tradition, keep vertical the axis of their section; and in the left section are drawn the ribs whose axis is directed toward the center.
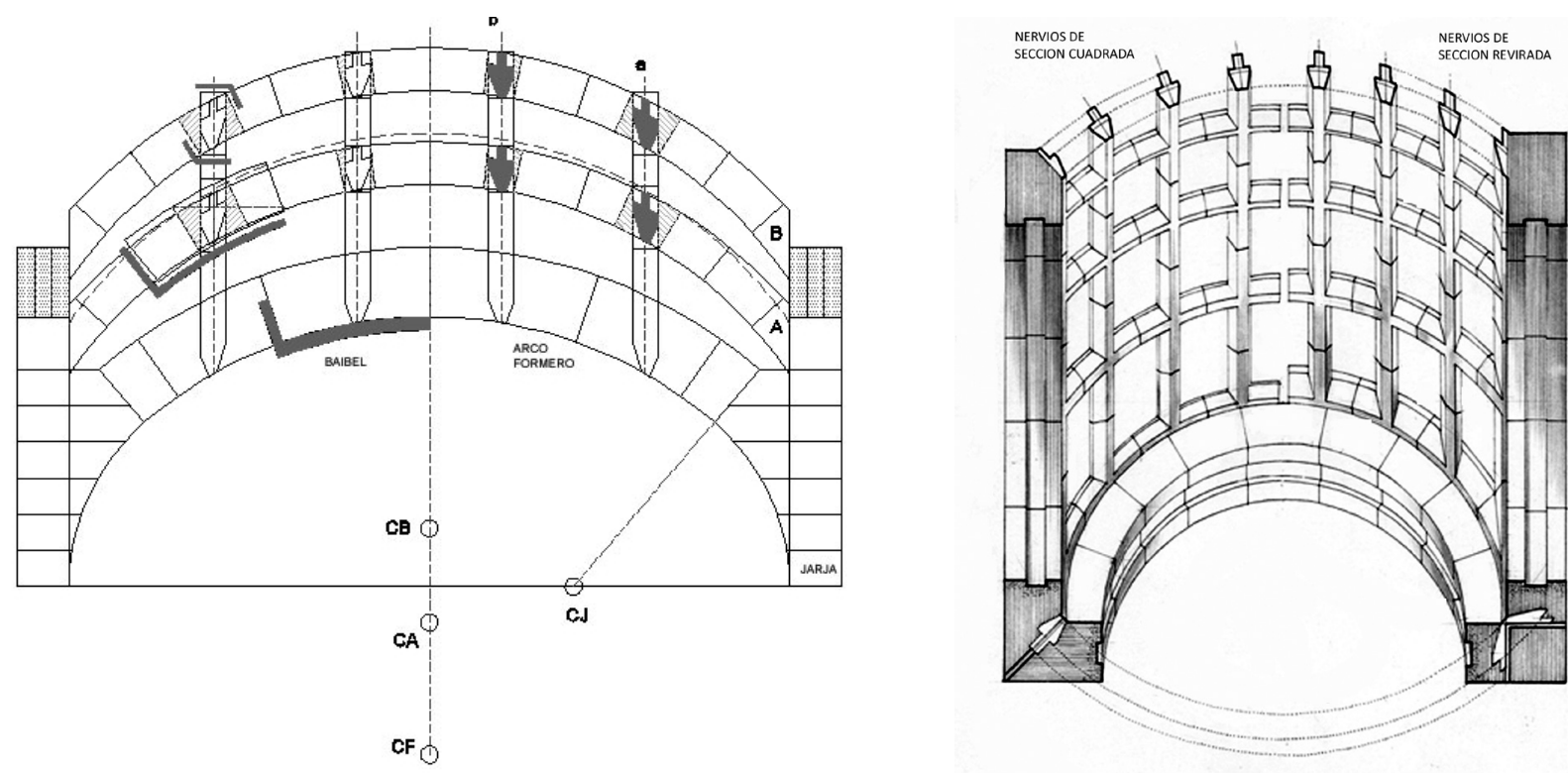
sobrante. Cabe señalar que en el Taller de construcción gótica del Departamento de Construcción de la Escuela Técnica Superior de Arquitectura de Madrid construimos una auténtica bóveda por cruceros siguiendo los procedimientos constructivos tradicionales utilizados en el siglo XVI. Por la facilidad y rapidez de labra, hemos utilizado escayola maciza en lugar de piedra.

En el modelo realizado en el Taller de la ETSAM, nos decantamos por la geometría más eficaz, aquella que permitiera estandarizar la bóveda de la manera más completa posible. Los arcos perimetrales serían arcos carpaneles y la parrilla de nervios se construiría con un solo arco, un arco que tendría la misma curvatura que la parte superior del óvalo perimetral. Este es el caso de las bóvedas de la sacristía en la parroquia de Carmona, Sevilla (Figura 7) en la que un mismo arco escarzano muy tendido se desplaza en ambas direcciones sobre arcos formeros en carpanel. Se trata de un ingenioso recurso que permite en gran medida simplificar $y$ racionalizar la estereotomía de las bóvedas por cruceros.

Así pues, tomando este ejemplo como modelo, la bóveda construida tiene sus arcos perimetrales ovales. La circunferencia superior de este óvalo es el arco que forma la parrilla ortogonal, mientras que, como veremos más adelante, las curvaturas inferiores forman las jarjas de la bóveda, lo cual facilita mucho su construcción. Por tanto, toda la bóveda se construye con un solo arco: la parte central del óvalo. Este arco, al desplazarse, genera una superficie de traslación formada por cuatro nervios en cada dirección. La talla de cada cruce se simplifica extraordinariamente ya que todos ellos se producen por la intersección de arcos de la misma curvatura.

Cruceros. Los cruceros son las piezas más importantes y complejas de la bóveda. La talla de estos elementos ponía a prueba como ningún otro la capacidad de los maestros de cantería. En las bóvedas góticas se resolvían los complicados cruces de arcos ocultando el difícil encuentro con una pieza cilíndrica vertical: la clave; sin embargo, en las bóvedas renacentistas, los encuentros de nervios se resuelven mediante la intersección limpia de los arcos: el crucero.

En la mayor parte de las bóvedas por cruceros españolas se aprecia como el crucero se define sobre una dovela larga en la que se tallan los otros dos brazos del crucero justo en el entronque (Figura 8). Este método facilita enormemente la ejecución de estas piezas, ya que el cálculo geométrico 16th century. In order to make the stonecutting easier and faster, we used solid plaster instead of stone.

In the model made in the workshop of the ETSAM, we opted for the most effective geometry, the one that could standardize the vault as completely as possible. The wall-arches would be basket arches and the rib grid would be built with a single arc, an arc which would have the same curvature as the top part of the perimeter oval. This is the case of the vaults of the sacristy in the parish church of Carmona, Seville (Figure 7) in which the same very spread segmental arc moves in both directions over transverse basket arches. It is a clever resource which allows to a large extent to simplify and rationalize the stereotomy of the grid crossing vaults.

So, taking this example as a model, the built vault has oval perimeter arches. The upper circumference of this oval is the arc that forms the orthogonal rib grid, while, as we will see later, the lower curvatures form the tas-de-charges of the vault, which facilitates greatly its construction. Therefore, the whole vault is built with a single arc: the central part of the oval. This arc, when moves, generates a translation surface formed by four ribs in each direction. The stone-cutting of each crossing is extremely simplified since all of them are produced by the intersection of arches of the same curvature.

Crossings. The crossings are the most important and complex vault pieces. The carving of these elements tested like no other the capacity of the Masters masons. In the Gothic vaults, the complicated crosses of arches were resolved by concealing the difficult encounter with a vertical cylindrical piece: the keystone. However, in the Renaissance vaults, the junctions of ribs are resolved through the clean arc intersection: the Crossings.

In most of the Spanish grid crossing vaults, it can be seen how the Crossing is defined on a long voussoir in which are built the other two arms of the crossing, right at the junction (Figure 8). This method facilitates greatly the implementation of these parts, since the geometric calculation of a pattern with its two complete arms is a delicate process from which may easily lead to errors. A simple deviation of the position of the arms would make it impossible to close the grid. Therefore, it is safer to carve an arm of the Crossing in its full length (main direction), and cut the other at its beginning (secondary direction) in order to prevent errors in the intersection angle. 


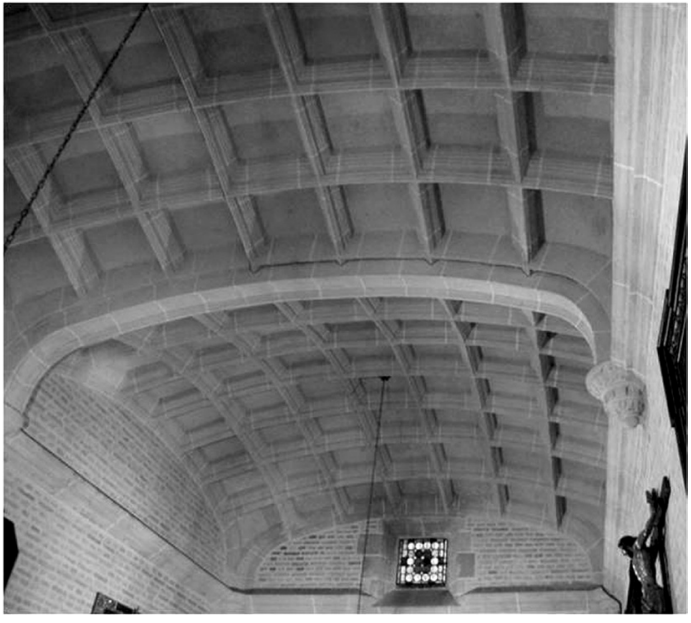

de un patrón con sus dos brazos completos es un proceso delicado del que fácilmente se pueden derivar errores. Una simple desviación de la posición de los brazos, haría imposible el cierre de la retícula. Por lo tanto es más seguro tallar un brazo del crucero con su longitud completa (dirección principal), y cortar el otro en su nacimiento (dirección secundaria) con objeto de prevenir errores en el ángulo de entronque.

En la talla de cruceros fue indispensable mantener una estricta nomenclatura para evitar confusiones a la hora de la puesta en obra. Como especificamos anteriormente, en la bóveda que construimos en la UPM se definieron cuatro tipos de cruceros:

Aa en cuya dirección principal contiene el revirado $A$ y en la dirección secundaría recibirá el revirado $A$.

$A b$ con dirección principal de revirado $A$ y dirección secundaria con revirado $B$.

$B$ a con dirección principal de revirado $B$ y dirección secundaria con revirado $A$.

$B b$ con dirección principal de revirado $B$ y dirección secundaria con revirado $B$.

De cada uno de estos cruceros se tallaron cuatro piezas, una para cada cuadrante, con lo que se obtuvieron los dieciséis cruceros necesarios para construir la bóveda (Figura 9).

La talla de un crucero ha sido resumida en la Figura 10. Como podemos observar, en su dirección principal, la labra se lleva a cabo como cualquier otra dovela, es decir, con la ayuda del baibel y de su correspondiente plantilla de testa. No obstante, una vez que se obtiene el sólido capaz de la dovela, se dibuja el eje vertical del cruce, dato este que se obtiene fácilmente de la montea. Se dibuja el prisma que contendrá a este cruce $y$, a continuación puede tallarse con la plantilla de testa el nervio principal respetando el prisma contenedor del cruce.

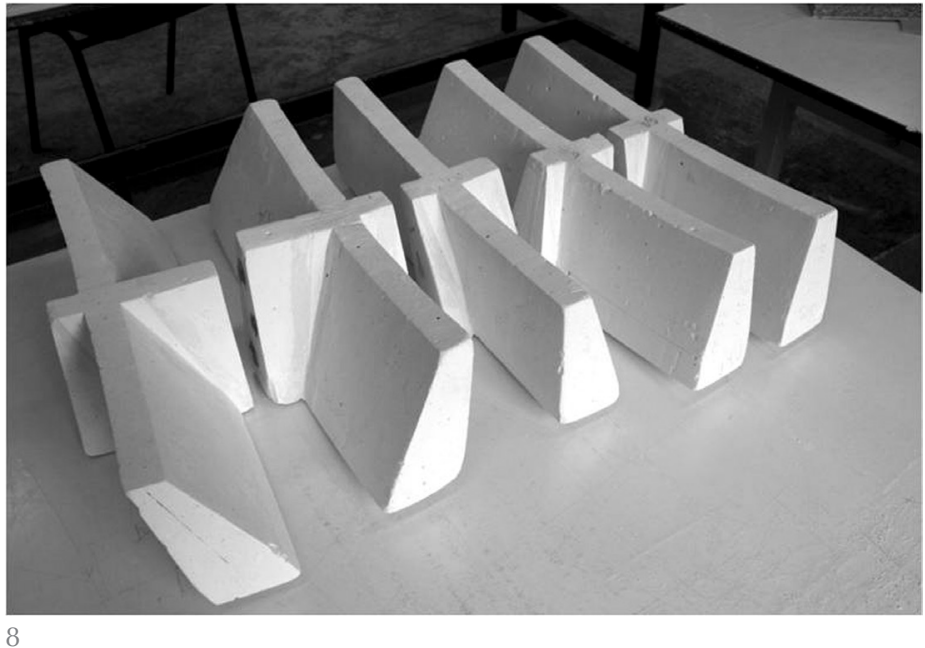

In the carving of crossings it was essential to maintain a strict nomenclature to avoid confusion at the time of the implementation. As we specified previously, four types of crossings were defined in the vault that we built at the UPM:

Aa in whose main direction contains the distorted section A and in the secondary direction will receive the distorted section $\mathrm{B}$. $\mathrm{Ab}$ with main direction of distorted section $\mathrm{A}$ and secondary direction with distorted section B.

Ba with main direction of distorted section $B$ and secondary direction with distorted section $\mathrm{A}$.

$\mathrm{Bb}$ with main direction of distorted section B and secondary direction with distorted section B.

Four pieces of each of these crossings were carved, one for each quadrant, obtaining the sixteen crossings required to build the vault (Figure 9).

The carving of a crossing has been summarized in Figure 10. As we can observe, in its main direction, the carving is carried out like in any other voussoir, that is, with the help of the bebel and its

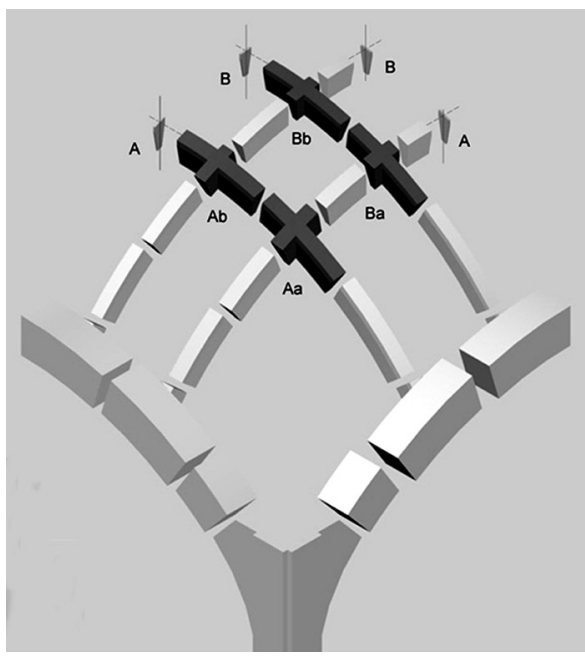

7. Bóvedas por cruceros gemelas. Sacristía. Iglesia de Santa María de la Asunción en Carmona, Sevilla. Autor: Diego de Riaño.

7. Twin grid crossing vaults. Sacristy. Church of Santa María de la Asunción in Carmona, Seville. Author: Diego de Riaño.

8. Encuentros de nervios resueltos mediante la intersección limpia de los arcos: piezas Ilamadas cruceros.

8. Crossing of ribs solved through the clean intersection of the arches: pieces called crossings.

9. Detalle de un cuarto de bóveda donde se aprecia la dirección principal y la dirección secundaria de las nervaduras; así como la combinación de los moldes revirados.

9. View of a quarter of a vault where can be seen the main direction and the secondary direction of the ribs, as well as the combination of the distorted patterns. 
10. Proceso de labra de un crucero por el método de la dirección principal.

10. Stone-cutting process of a crossing using the method of the main direction
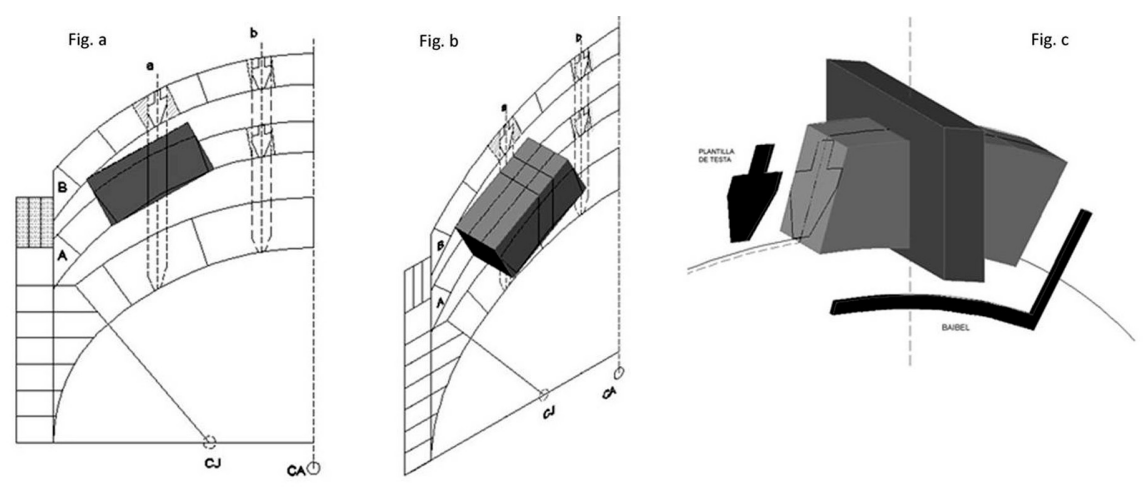

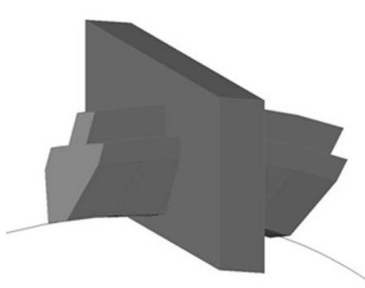

Fig. $d$

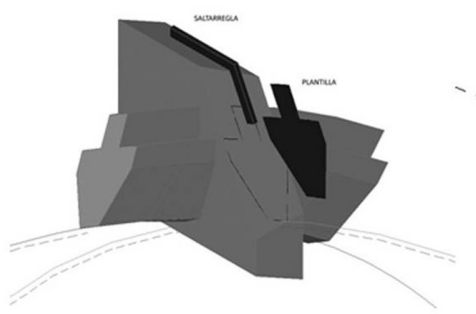

Fig. e

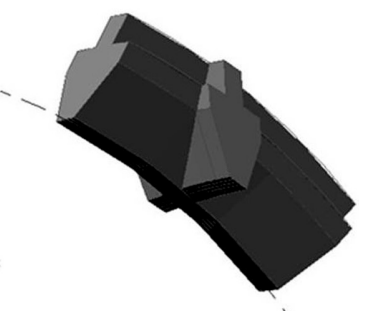

Fig. $f$

10

Una vez que la dirección principal tiene la forma adecuada se procede a tallar la dirección secundaria en el prisma central; para ello, en primer lugar, se debe cortar con la debida inclinación las testas de los arcos que concurren en este crucero. Para llevar a cabo el corte hemos de conocer los ángulos de acometida de estos arcos, ángulos que se obtienen de la montea vertical de la bóveda, mediante un compás de ángulos o saltarregla. Los ángulos de acometida se determinan en relación al plano horizontal, ya sea el superior o el inferior del prisma. El ángulo se traslada a la piedra y permite dar el corte adecuado a las testas de cada arco.

Jarjas. En una bóveda gótica de crucería, los nervios parten de sus cuatro vértices; el racimo de arranque de las nervaduras, en el siglo XVI, recibía el nombre de jarja y era una de las partes fundamentales de la bóveda. Esta pieza se talla siempre por lechos horizontales. Sin embargo, en el caso de las bóvedas por cruceros, los nervios acometen lateralmente contra los arcos perimetrales $y$, en consecuencia, los empujes horizontales que estos generan, descargan perpendicularmente sobre ellos. Las bóvedas por cruceros, requieren que estos empujes se contrarresten lateralmente colocando una bóveda junto a otra. Esta es la razón constructiva y de estabilidad por la cual, en la mayoría de los casos, los templos que se cubren con bóvedas por cruceros tienen la misma altura en todas sus naves.

Mencionamos anteriormente que los arcos perimetrales de la bóveda que se construyó en la ETSAM, son arcos ovales, es decir, un arco compuesto de tres curvas: la central y corresponding testa pattern. However, once obtained the solid capable of supporting the voussoirs, the vertical axis of the crossing is drawn; this information is easily obtained from the montea. The prism which will contain this crossing is drawn and, then, the main rib can be carved with the testa (front) pattern, respecting the prism that contains the crossing.

Once the main direction has the right shape we proceed to carve the secondary direction in the central prism; to do this, first of all, we must cut with the right inclination the sections of the arches which meet in the crossing. To do the cutting we must know the arrival angles of these arches; these angles are obtained from the vertical montea of the vault with a compass of angles or saltarregla. The arrival angles are determined in relation to the top horizontal plan or the bottom plan of the prism. The angle moves to the stone and enables to give the precise cut to the sections of each arch.

Tas-de-charge. In a Gothic grid crossing vault, the ribs spring from their four vertices; the starting point of the ribs, in the 16th century, was called tas-de charge and was one of the essential parts of the vault. This piece is always built in a horizontal position. However, in the case of the grid crossing vaults, the ribs cross laterally against the wall-arches and, consequently, the horizontal thrusts that these generate, come upon them perpendicularly. The grid crossing vaults require that these thrusts counteract laterally by placing one vault next to another. This is the constructive and stability reason why, in most cases, 
dos más pequeñas en sus extremos. En bóvedas construidas que tuvimos ocasión de estudiar, pudimos observar que estos pequeñas curvas determinan exactamente la altura de las jarjas, es decir que, el punto de tangencia entre los arcos del óvalo es el nivel máximo que deben alcanzar las jarjas. Los extremos del óvalo no son por tanto arcos autónomos sino que forman parte del macizo de arranque de la bóveda que debe construirse con lechos horizontales. Este es un recurso muy eficaz que, por una parte, facilita sobremanera la talla de los arcos fajones y, por otra, simplifica la bóveda al tener toda ella un sólo radio de curvatura.

Para la construcción de la jarja se recurre de nuevo a la montea, en la que aparecen dibujados los lechos horizontales que forman las jarjas. Con estos dibujos se elaboran una serie de plantillas que permitan taIlar cada lecho. La plantilla inferior se calca en el plano inferior del sillar, y la plantilla superior sobre la cara superior. Posteriormente se procede a la labra enlazando una cara con la otra. Como la última jarja recibe los arcos formeros, se talla con la inclinación necesaria para entrar en contacto con la primer dovela; este dato se toma de la montea en alzado. Así pues, el arco formero sólo funciona estáticamente como arco por encima del nivel de jarja (Figura 5).

Cimbra. Una vez que los canteros terminaban la labor de talla de dovelas, cruceros y jarjas, se producía el replanteo de la bóveda colocando las jarjas en su lugar preciso, es decir, sobre las columnas. Es entonces cuando se hacía necesario el concurso de la carpintería de armar para la confección de las cimbras, cuyo diseño comenzaba con la construcción de una plataforma horizontal situada a la altura de las jarjas. (Figura 11). Cabe mencionar que para la construcción de la cimbra se siguieron las recomendaciones de Rodrigo Gil de Hontañón (1540) que aparecen en el tratado de Simón García (7).

Sobre la plataforma de madera se redibujaba de nuevo la planta de la bóveda localizando así los puntos de cruce. Sobre cada uno de ellos se colocaban pies derechos con la altura exacta de cada cruce, medida ésta que de nuevo puede obtenerse fácilmente de la montea en alzado. Por último, los pies derechos se unían entre sí mediante las cimbras curvas de los arcos (recordemos que los nervios comparten la misma curvatura, por lo que los arcos de madera son iguales) formando la retícula espacial de la bóveda, sujetando unos con otros y estabilizando toda la estructura.

Obsérvese que este tipo de bóvedas se beneficia del ingenio gótico también en la the churches that are covered with grid crossing vaults have the same height in all their naves.

We mentioned before that the edge wallarches of the vault which was built at the ETSAM, are oval arches, that is, archers consisting of three curves: the central and two smaller ones at their ends. In built vaults which we had the opportunity to study, we could observe that these small curves determine accurately the height of the tas-de-charge, that is, the tangent point between the arches of the oval is the maximum level that has to be reached by the tas-de-charge. Therefore, the ends of the oval are not single arches, they are part of the massif springing of the vault and must be built with horizontal layers. This is a very effective resource which, on the one hand, facilitates greatly the building of the edge arches and, on the other, simplifies the vault since it only has a single curvature radius.

Once again, for the construction of the tasde-charge we use the montea, where are drawn the horizontal layers that form the tas-de-charges. With these drawings we make a series of templates which enable us to build each layer. We trace the bottom pattern on the lower plan of the ashlar, and the top pattern on the top face. Then we proceed to carve it by linking one side with the other. Since the last tas-de-charge receives the transverse arches, we build it with the adequate inclination to make it come into contact with the first voussoir; this information is taken from the montea in elevation. So, the edge arch only works as an arch above the level of the tas-de-charge (Figure 5).

Centering. Once the masons ended the carving of the voussoirs, crossings and tasde-charges, they started the construction of the vault by placing the tas-de-charges in theirs precise places, that is, on the pillars. Then, it was necessary the concurrency of a significant woodwork to prepare the centering, whose design began with the construction of a horizontal platform located at the height of the tas-de-charge (Figure 11).It is worth noting that for the construction of the centering were followed the recommendations of Rodrigo Gil de Hontañón (154), which appear in the Treaty of Simón García (7).

In order to find the crossing points, the ground plan of the vault was drawn on the wooden platform once again. On each of them were placed wooden pillars with the exact height of each crossing. Again, this information could be easily obtained from the montea in elevation. Finally, the 
construcción de las cimbras. Una bóveda encasetonada romana tradicional construida en cal y canto o adovelada, hubiera requerido una estructura completa de madera, un encofrado, capaz de soportar la totalidad del peso de la bóveda. Sin embargo, al estar construida mediante nervios, a la usanza gótica, la cimbra debe soportar únicamente el peso de cada arco mientras éste se está construyendo. Es importante señalar que, una vez que cada arco está acabado, es él mismo el que actúa de cimbra recibiendo el peso que le corresponda de la bóveda; las cimbras de madera por tanto pueden ser mucho más ligeras y económicas (9).

Puesta en obra. Una vez terminada la cimbra, se procedía a construir los arcos perimetrales. Posteriormente se colocaban las dovelas y los cruceros de la dirección principal y finalmente se completa la retícula con la colocación de las dovelas de la dirección secundaria. En el montaje, las juntas entre dovelas requieren gran atención ya que, un correcto alineamiento de las dovelas que forman un arco, exige colocarlas separadamente de forma que los errores de talla entre sus caras no impidan su correcto alineamiento. Las juntas se colmaban con un mortero de cal.

Cuando la retícula de la bóveda estaba lista, se procedería a colocar los casetones, es decir, las piedras que cubren el espacio entre los nervios, y así se obtenía la superficie completa de la bóveda. Se puede decir que los fondos de los casetones son la plementería de este tipo de bóvedas. En una bóveda de traslación, como los huecos que quedan entre los nervios forman un cuadrilátero coplanario, podría cerrarse con una piedra plana cortada con la forma adecuada. En la experiencia docente se tomó la decisión de no ejecutar los casetones para que la red de nervaduras se perciba con mayor claridad. En particular, puede apreciarse cómo gracias a los revirados de los arcos y cruceros, por el trasdós, se obtiene una superficie enteramente lisa que permite recibir correctamente la plementería (Figura 11).

Descimbrado. La bóveda no estaba del todo terminada hasta que las cimbras de madera no se retiraban. Sólo entonces la bóveda revelaba toda la belleza de su geometría. El descimbrado de la bóveda por cruceros que construimos en la UPM fue filmado por el servicio de tele educación de la Universidad Politécnica de Madrid. Se puede ver en la página web www.bovedasgoticasdecruceria.com. wooden pillars were joined together by the curved centering of the arches (remember that the ribs have all the same curvature, so the wooden arches are equal) forming the spatial grid of the vault, holding each other and stabilizing the whole structure

Note that this type of vaults benefits from the Gothic inventiveness also in the construction of the centering. A traditional Roman vault, built of lime and stone and covered with caissons or voussoirs would have required a whole wood structure capable of supporting the entire weight of the vault. However, since it is built with ribs, the centering must support only the weight of each arc while it is being built. It is important to point out that, once each arc is finished, it acts as centering receiving the corresponding weight from the vault; therefore, wooden centering can be much more economical and lighter.(9)

Assembling the vault. Once the centering was finished, we proceeded to build the wall-arches. Next, we placed the voussoirs and crossings of the main direction and finally completed the grid with the placement of the voussoirs of the secondary direction. The placement of the joints between voussoirs requires especial care since a correct alignment of the voussoirs which form an arc, means placing them separately so that the errors of the carving between their faces do not prevent their correct alignment. Joints were filled with a lime mortar.

When the grid of the vault was ready, we proceeded to place the caissons, that is, the stones which cover the space between the ribs, and this way we obtained the full surface of the vault. In a vault of translation, as the gaps between the ribs form a coplanar quadrilateral, that could be closed with a flat stone cut into the appropriate shape. In our teaching experience we decided not to implement the caissons so that the grid of ribs could be perceived more clearly. We can also observe how, thanks to the distorting sections of the arches and crossings, in the extrados, we obtain an entirely smooth surface which allows to place the vaulted shell correctly (Figure 11).

Removing the centering. The vault was not fully complete until the wooden centering had not been removed. Only then, the vault revealed all the beauty of its geometry. The removing of the centering of the grid crossing vault which we built at the UPM was filmed by the service of teleeducation of the Universidad Politécnica de Madrid. It can be seen in the webpage www.bovedasgoticasdecruceria.com. 


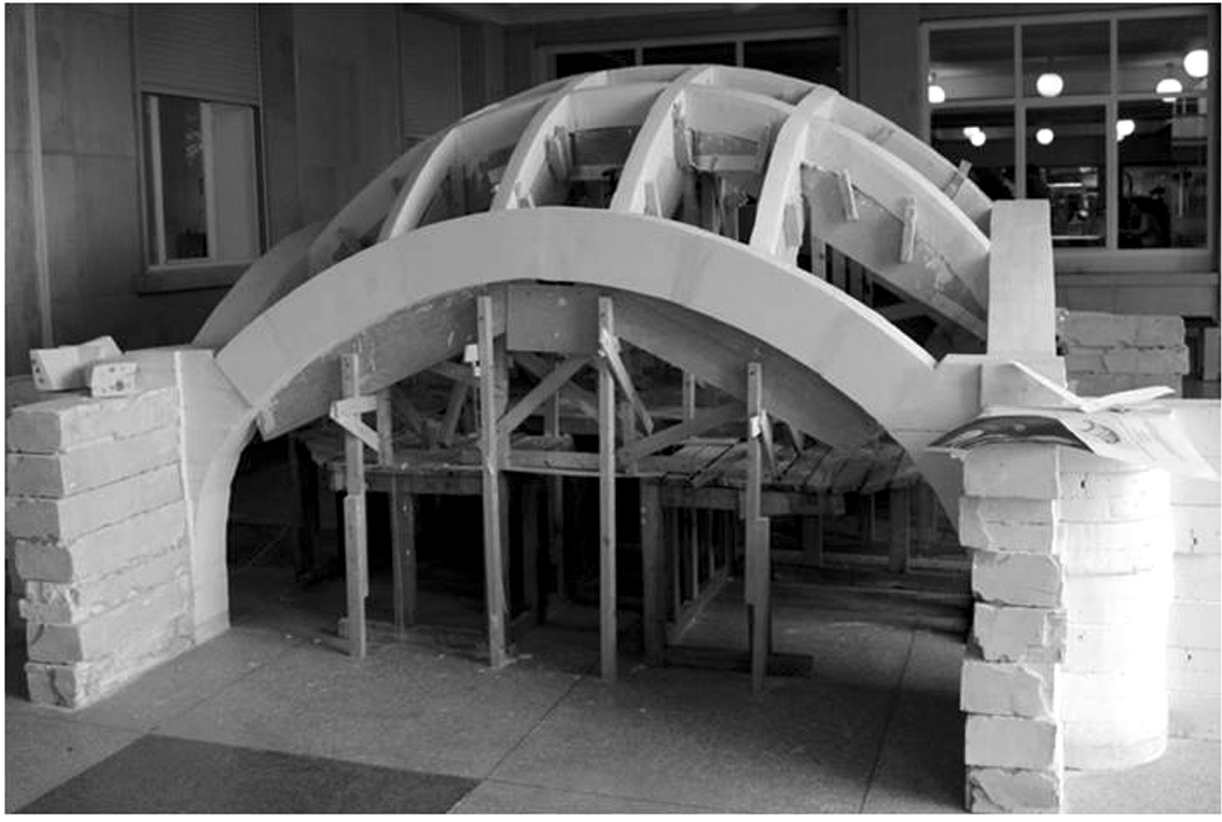

\section{CONCLUSIÓN}

El estudio de las bóvedas por cruceros es una extraordinaria oportunidad para acercarnos a la compleja realidad profesional de la arquitectura española del siglo XVI. Un mundo en el que el gótico, lejos de desaparecer, experimenta su momento culminante, su pleno desarrollo, gracias al conocimiento y a la técnica de una serie de arquitectos que siguieron explorando las posibilidades técnicas y expresivas de esta arquitectura "moderna" en el decir de entonces. Este mundo obligó y condicionó el desarrollo de la arquitectura renacentista española que, aunque parte de principios estéticos radicalmente diferentes, mantiene la tradición constructiva medieval y se construye igualmente en piedra.

Sin el conocimiento de la construcción, como parte indisoluble de la arquitectura, toda aproximación al proceso creativo de la arquitectura es inexplicable; el texto que acabamos de exponer lo pone en evidencia. Sin una definición constructiva de las bóvedas por cruceros es imposible comprender este importante capítulo del quehacer arquitectónico del siglo XVI en España.

\section{CONCLUSION}

The study of the grid crossing vaults is an extraordinary opportunity to approach to the complex professional reality of the Spanish architecture of the 16th century. A world in which the Gothic style, far from disappearing, experiences its highest point, its full development, thanks to the knowledge and technique of a number of architects who continued exploring the technical and expressive possibilities of this "modern" architecture, as it was said in those times. This world forced and conditioned the development of Spanish Renaissance architecture which, although it starts from radically different aesthetic principles, maintains the medieval constructive tradition and also uses stone in building.

Without the knowledge of construction, as an indissoluble part of architecture, any approach to the creative process of architecture will be unexplainable; the text that we have just exposed shows that. Without a constructive definition of the grid crossing vaults, it is impossible to understand this important chapter of the architectural work of the $16 \mathrm{~h}$ century in Spain.

\section{REFERENCIAS / REFERENCES}

(1) Morón de Castro, M. F. (1995). La iglesia de San Miguel. Cinco siglos en la historia de Morón de la Frontera XVI-XVIII. Sevilla: Universidad de Sevilla, Fundación Fernando Villalón.

(2) Morales Martínez, A. (1981). La obra renacentista del ayuntamiento de Sevilla. Sevilla: Ayuntamiento de Sevilla.

(3) Rodríguez Estévez, J. (1998). Los canteros de la catedral de Sevilla. Sevilla: Diputación de Sevilla. 
(4) Barbé-Coquelin de Lisle, G. (1977). Tratado del arquitecto Alonso de Vandelvira. Albacete: Caja de Ahorros Provincial.

(5) Palacios Gonzalo, J. C. (2003). Trazas y cortes de cantería en el Renacimiento español. Madrid. Munilla-Lería.

(6) Bravo Guerrero, S. C. (2011). Bóvedas por cruceros, clasificación geométrica. En Actas del séptimo Congreso Nacional de Historia de la Construcción. Santiago de Compostela: Instituto Juan de Herrera y la Escuela Técnica Superior de Arquitectura de Madrid. pp. 161-167.

(7) García, S. (1681). Compendio de arquitectura y simetría de los templos. Publicado por Colegio Oficial de Arquitectos de Valladolid, estudios introductorios de Antonio Bonet Correa y Carlos Chanfón Olmos. Valladolid. 1991.

(8) Gómez Martínez, J. (1998). Bóvedas de crucería. El gótico español en la edad moderna. Valladolid: Universidad de Valladolid.

(9) Palacios Gonzalo, José C. (2009). La cantería medieval, la construcción de la bóveda gótica española. Madrid: Munilla-Lería. 